\title{
Not in Anyone's Backyard? Civil Society Attitudes towards Wind Power at the National and Local Levels in Portugal
}

\author{
Ana Delicado, Luís Junqueira, Susana Fonseca, Mónica Truninger, Luís \\ Silva, Ana Horta and Elisabete Figueiredo
}

This article attempts to explain the swift development of renewable energy, in particular wind energy, in Portugal, by assessing the socio-political, community and market acceptance of renewables. We examine, on the one hand, the institutional and policy framework, the approaches to planning, and the ownership of facilities, and, on the other hand, the attitudes of Environmental Non-Governmental Organisations and citizens towards renewable energy in general and local windfarms in particular. Results show that a highly attractive feed-in tariff system and a system of planning decisions at the national level has led to an expansion of wind power, regardless of a less than enthusiastic public opinion and a sceptical environmental movement.

Keywords: renewable energy, public opinion, environmental non-governmental organisations

\section{Introduction}

In March 2007, the leaders of the European Union (hereafter EU) made a commitment to implement a highly energy-efficient low carbon economy (EC, 2007). Two years later, through the climate and energy package, they agreed on a set of targets known as the “20-20-20" (EC, 2010), establishing three key objectives for 2020: a $20 \%$ reduction in EU greenhouse gas emissions from 1990 levels; an increase of $20 \%$ of the share of energy produced from renewable sources in the EU; a $20 \%$ improvement in the EU's energy efficiency. Among these key objectives, the most relevant for the present article is the one related to the share of renewable energy (hereafter RE) sources in the overall energy consumption in the EU. This objective has been the main driver for investments in RE across Europe.

The position of Portugal in European rankings concerning social and environmental indicators is usually low. But, when it comes to RE, Portugal is at the top of the list. The percentage of RE in total consumption is already $25 \%$ (the goal for 2020 is $31 \%$ ), which places Portugal in the sixth place in the ranking of the 27 EU member states (Eurostat, 2011). This is mainly due to hydro power (whose inclusion as RE is debatable) and to wind 
energy, with close to 240 windfarms operating in the country and a few others under construction. Can this be due to a widespread acceptance of RE, both at the general and the local level? Is civil society in Portugal strongly in favour of wind and solar energy? Or, are there other factors at play when it comes to implementing policies aimed at sustainable energy systems?

The two main purposes of this article are to understand the conditions that made possible a swift development of wind energy and to assess civil society's attitudes towards this energy source in Portugal. We have chosen two types of social actors who are usually defined as representatives of civil society - citizens and Environmental NonGovernmental Organisations (hereafter ENGOs) - and two scales at which to gauge their attitudes: the national level, scrutinized by using public opinion surveys and interviews with representatives from ENGOs; and the local level, studied by using the participation of citizens and ENGOs in public consultations of Environmental Impact Assessment (hereafter EIA) processes of windfarms.

\section{Literature Review}

Energy issues are urgent environmental, economic, political, and social challenges. The threats of climate change and the scarcity of conventional energy sources have led many European countries to increasingly invest in alternative, renewable energy sources. Despite a common agenda set by the EU, European countries have experienced different levels of success in implementing RE. In 2011, RE represented $20 \%$ of electricity generation in the EU 27, but with great internal variations: from over $40 \%$ in Sweden, Austria, Portugal and Latvia, to under $10 \%$ in Belgium, the United Kingdom (hereafter UK) and several Eastern European countries (Eurostat, 2013a).
Besides the more traditional hydro power, which is still the main provider of RE, wind energy accounts for much of the growth in RE in Europe. In 2011, it was responsible for generating close to 180 thousand gigawatt hour in the EU27, whereas solar photovoltaic generated only 45 thousand gigawatt hour and tide, wave and ocean energy are still underdeveloped, with 500 gigawatt hour (Eurostat, 2013b).

Several authors have looked into the differences between countries in terms of policy and institutional framework for explaining the diversity in the level of development of wind energy. Wolsink (2000) examined the cases of the Netherlands and Germany, and ascertained that the greater development of wind power in the latter could be attributed to the feed-in tariff, whereas the low level of implementation in the former is due to structural barriers in the electric sector, the actions of political actors and the opposition of ENGOs. Some years later, the same author (Wolsink, 2007a) expanded his comparative scope and sought to understand the rapid wind development in Germany, Denmark and Spain, the slower growth in Sweden, Italy, Greece and France, and the sluggishness in the Netherlands and the UK. He identified as relevant variables the planning regime, the financial support system, the values attached to landscape quality and preservation, and the degree of local ownership of schemes to build windfarms, concluding that the main barrier to wind power development is the topdown planning of large scale developments and that participatory open-ended approaches are fundamental. Similarly, Loring's (2007: 2658) comparison between England, Wales and Denmark verified that "projects with high levels of participatory planning are more likely to be publicly accepted and successful". Conversely, Toke (2005) ascertained that the rate of planning permission approvals is quite low in the UK, 
but that the development of wind energy has been hindered mainly by problems in the financial incentive system and the lack of uptake by developers (only two thirds of the capacity of contracts issued has even applied for planning permissions). Bell, Gray and Hagett (2005) offer different explanations for the (relative failure) of wind energy in the UK (democratic deficit, qualified support and self-interest) and propose several policy measures that can address them. More recently, the same authors (Bell et al., 2013) expanded their analysis to include place attachment (see below), the relationships between factors, concerns about landscape and fairness, and local relations of power.

Also regarding the policy and institutional frameworks of RE, Jobert, Laborgne and Mimler (2007) drew comparisons between France and Germany and highlighted the role played both by institutional conditions, such as economicincentives and regulations, and by site-specific conditions (territorial factors), such as the local economy, the local geography, local actors and the actual on-site planning process (project management). Breukers and Wolsink (2007) focused again on the cases of Germany (only one of its states), the Netherlands, and the UK and sustain that institutional capacity building is the fundamental factor in wind power development, combining financial incentives, local bottom-up mobilisation and the formation of policy communities. Another, wider, cross-country study by Toke, Breukers and Wolsink (2008) attributes the diverse levels of wind power development in Denmark, Spain, Germany, the Netherlands, Scotland and England to differences in planning systems, financial support mechanisms, the actions of landscape protection and the patterns of ownership of wind power.

Another dimension that many of these studies also cover, but takes center stage in other published research, is the civil society reactions to wind energy and the siting of windfarms. Several authors have sought to explain the success or failure of wind energy development by examining three types of data: attitudes of the general public towards wind energy, ENGOs positions and localised case studies on the resistance to the setting up of windfarms.

With respect to the first, most studies ascertain that public opinion surveys show a generalised support for RE and even for wind energy (Walker, 1995; Ek, 2005; Bell, Gray \& Haggett, 2005; Wolsink, 2007b; Aitken, 2009), usually perceived as "clean", "green" or "environmentally friendly" and as an extension of traditional technologies like wind mills (Pasqualetti, 2001; Nadaï \& van der Horst, 2010). However, some authors have pointed out that public opinion on $\mathrm{RE}$ is also not homogeneous: there are many "publics", and attitudes vary across social groups (Walker, 1995; Ek, 2005). Nevertheless, in many cases, literature in this area has identified what has been called a "dilemma" (Barry, Ellis \& Robinson , 2008), a "social gap" (Bell, Gray \& Haggett , 2005; Breukers \& Wolsink, 2007), or an "attitudebehaviour gap" (Haggett \& Futák-Campbel, 2011): a mismatch between generalised support to RE and local opposition to the siting of energy-generating facilities, particularly windfarms.

Regarding the particular case of ENGOs, Warren et al. detected what they call a "green on green" controversy: "in the case of wind power there are strong 'green' arguments on both sides of the debate. Some environmentalists advocate windfarms because of their 'clean energy' credentials, while others oppose them because of their landscape impacts. Still others are caught awkwardly in the middle, supporting renewable energy in principle but opposing specific windfarm proposals" (Warren et al., 2005: 854). Other authors also highlight 
the critical stance of ENGOs (especially at the local level, against windfarms in particular locations) as a barrier to the development of wind energy in some countries (Walker, 1995; Wolsink, 2000, 2007a; Bell, Gray \& Haggett, 2005; Breukers \& Wolsink 2007; Cowell, 2010). However, it must be noted that opposition to windfarms stems mainly (but not exclusively) from landscape protection ENGOs, particularly active in the UK, whereas in Germany and Denmark some ENGOs actively support the development of renewables (Toke, 2005; Breukers \& Wolsink, 2007; Loring, 2007; Toke, Breukers \& Wolsink, 2008).

Although windfarms present very few risks, controversies have arisen in most countries, motivated by concerns over issues such as noise, pollution, health effects and impacts on wildlife (especially birds and bats), but also the perception that the turbines ruin the countryside and threaten natural and cultural heritage, with not only symbolic consequences, but also on tourism and the economic value of properties (Nadaï \& van der Horst, 2010; Wolsink, 2007a; Cowell, 2010; DevineWright \& Howes, 2010; Havas \& Colling, 2011; Phillips, 2011).

In the 1980s and 1990s local opposition to the siting of facilities with presumed environmental impacts was often characterised as NIMBY (Not In My Backyard) reactions, that acknowledged the need for such facilities, but refused to accept them in the vicinity (Dear, 1992; Wolsink, 2000). Most current studies on windfarms stress the uselessness of that concept, emphasising instead issues such as feelings of place attachment and identity, planning procedures, perceptions of fairness, transparency and environmental justice, lack of confidence in government and companies, dearth of opportunities for citizen participation and engagement (Walker, 1995; Devine-Wright, 2005; Bell
Gray \& Haggett, 2005; Jobert, Laborgne \& Mimler, 2007; Breukers \& Wolsink, 2007; Wolsink, 2007a, 2007b; Barry, Ellis \& Robinson, 2008; Aitken, 2009; DevineWright \& Howes, 2010; Haggett \& FutákCampbel, 2011). In addition, there is neither empirical evidence for the connection between oppositions to windfarms with geographical distance (Walker, 1995; Wolsink, 2000, 2007b; Devine-Wright, 2005; Warren et al., 2005; van der Horst, 2007) nor with positive attitudes towards RE in general (Ek, 2005; Warren et al., 2005; Eltham, Harrison \& Allen, 2008).

In an introduction to a special issue of Energy Policy (where several of the works cited above were published), Wüstenhagen, Wolsink and Burer (2007) propose a model of social acceptance of renewable energy that encompasses the variety of actors involved and that takes into account both the institutional framework and the siting of specific infrastructures, in short the national and local level. The authors put forward three dimensions of acceptance: sociopolitical, community and market. The first combines the acceptance by the general public (measured generally by public opinion surveys), by key stakeholders and by policy makers. Community acceptance refers to "the specific acceptance of siting decisions and renewable energy projects by local stakeholders, particularly residents and local authorities" (Wüstenhagen, Wolsink \& Burer, 2007: 2685) and is conditioned by perceptions of distributive justice (the allocation of costs and benefits), procedural justice (a fair and participated decision-making process) and trust in promoters. Market acceptance relates to the consumers (in the case of distributed production of energy and green power marketing), investors and intra-firms.

This article seeks to contribute to the existing literature by discussing the case of a southern European country where 
wind energy development has been significant and swift, but that has been left out of international comparisons, namely, Portugal. In order to draw comparisons with the literature in this area, we will examine the institutional and policy frameworks, in particular the financial incentives, the approaches to planning and the ownership of facilities, on the one hand, and the attitudes of ENGOs and citizens towards renewable energy in general and local windfarms in particular, on the other hand. The purpose, therefore, is to assess both the socio-political, community and market acceptance of renewables in Portugal. For this purpose, we have opted for a combination of extensive methods.

\section{Methodology}

Data on the policy and institutional framework comes mostly from document analysis: legislation, policy papers and programmes, parliamentary debates, news articles, companies' reports and websites. The time scope of the document analysis ranges between 1988 and 2013.

The analysis of civil society attitudes towards wind energy combines empirical data from three main sources. Firstly, public opinion data on RE were gathered from Eurobarometer surveys (Eurobarometer 65.3, 2007; Eurobarometer 69.2, 2008; Eurobarometer 73, 2010; Eurobarometer $75.4,2011)$, whose databases were accessed via the ZacatGesis website. Data treatment consisted of extracting survey results from Portugal and the EU average of variables related to attitudes towards wind energy. Despite its benefits, notably in terms of cross-country comparisons, Eurobarometer surveys have limitations: the questionnaires are created for policy, rather than scientific aims, and the way questions are built do not fully fit the intended research objectives (Nissen, 2013).
Information on the position of ENGOs regarding $\mathrm{RE}$ stems from two different empirical techniques: content analysis of documents (publications, reports, position papers, interventions in seminars, press releases) and interviews with ENGOs' representatives. Six national ENGOs were selected, based on their actions regarding RE (awareness campaigns, public statements, participation in consultation procedures of EIA of windfarm projects): three are the largest ENGOs in Portugal and have a broad scope of action, and the other three are focused mainly on fauna conservation. The interviews were conducted either with the president or with a representative from the specific working group dealing with RE. The interviews were recorded and fully transcribed, and content analysis was undertaken.

Thirdly, local attitudes towards RE were assessed through an analysis of Public Consultation Reports (hereafter PCR) of EIA processes regarding windfarms. We collected 76 PCR, concerning 83 EIA of windfarms, carried out between 2001 and 2012, from the archive of the Portuguese Environmental Agency. These PCR summarize the written comments sent in by public and private entities and were coded in a QDA software to build a database of written comments, identifying the entity that produced them and the orientation of the comment - positive, negative, or conditional. Particular attention was paid to the statements from civil society (citizens, citizen groups, Commons Councils, local entrepreneurs, ENGOs). These data were both used to extract overall statistics on participation in the public consultation of windfarms' EIA and to draw data for discourse analysis.

The data from the PCR have some limitations, since there are some differences in access to the public consultation process by different kinds of stakeholders, mostly 
due to how information is spread. NGOs and the local authorities are directly informed of the public consultation by the National Environment Agency, but the local population is dependent on the publicity of the public consultation by local authorities, whose interests can be opposed to a broad public discussion of the project (Chito \& Caixinha, 1993; Gonçalves, 2002).

In addition, the interviews with the ENGO representatives also provided some information on the limitations of the PCRs as a source of data. The high number of windfarm EIA processes over the last few years limited the NGO's capacity to participate in public discussions as they have limited resources and must divide their attention across several environmental issues.

Much of the research literature in this area has relied on localised case studies, concerning one or perhaps two windfarm projects (Woods, 2003; Warren et al., 2005; Eltham, Harrison \& Allen, 2008; DevineWright \& Howes, 2010; Aitken, 2009). Some publications (Jobert, Laborgne \& Mimler, 2007; Loring, 2007) compare the results of several case studies. The work based on local studies has its own strengths, but for the Portuguese context, where the implementation of wind energy was product of a centralized process developed over a short period of time, it is important to also grasp this issue at a broader level.

Toke (2005) followed this kind of approach, by looking at 51 planning applications for windfarms, with their respective decisions, recommendations from local parish councils, planning authorities, conservation and landscape groups. Through a regression analysis, he sought to identify the conditions for approval or rejection of the windfarms. Van der Horst and Toke (2010) also examined the planning decisions of windfarms and appeals in the UK to look at associations with a wide array of geographical and socioeconomic variables. They ascertained that less affluent areas have a higher rate of approvals, which is evidence for environmental injustice and the critical role played by social capital.

Another strand of studies concerns discourse analysis of wind energy supporters and opponents (decisionmakers, companies, citizens, ENGOs, local authorities) with recourse to interviews and documents (Barry, Ellis \& Robinson, 2008; Cowell, 2010; Haggett \& Futák-Campbel, 2011). The study by Haggett and Toke (2006) explored how this two approaches can be used simultaneously, providing complimentary insights into the wind power planning process. In a similar fashion, this article combines empirical data from three main sources, both quantitative and qualitative, at the national and local levels, to provide a better understanding of civil society's attitudes towards wind power.

\section{Development of Wind Power in Portugal}

In the past decade, Portugal has made an extensive investment in RE generation. The ambitious target of $45 \%$ of electricity from RE sources by 2010 was met and the percentage of $\mathrm{RE}$ in total consumption is already $25 \%$ (the goal for 2020 is $31 \%$ ). The main source of electricity through RE is still hydro power (43\%), but by a very short margin, since wind energy now represents $42 \%$ of renewable energy generation, a sharp increase from the $6 \%$ registered in 2004 (DGEG, 2012). In fact, windfarms have grown exponentially in the last decade. After a slow start in the 1990s, with just 18 windfarms functioning by the end of the decade, in December 2013 there were close to 250 windfarms in the country. These windfarms have a total of 2,474 turbines, with the total capacity of 4,730.5 MW (INEGI, 2013). 
This sudden development can be explained by a very favourable policy framework in the past decade (in line with the findings of Wolsink, 2000; Ringel, 2006; Breukers \& Wolsink, 2007; Toke, Breukers \& Wolsink, 2008), as well as by the uptake of wind energy by the private sector. Following Wüstenhagen, Wolsink and Burer 's (2007) model, the political and market acceptance of renewables is assured in Portugal. The first legislation concerning feed-in tariffs for renewable energy was issued in $1988^{1}$ but only a decade later, in $1999^{2}$, was it revised in order to provide stronger financial incentives. In the same year, the 4E programme (Energy Efficiency and Endogenous Energies) ${ }^{3}$ was launched, with the ambitious aim of achieving $39 \%$ of renewable energy in electricity generation in a decade. Subsequently, in 2002, the first tender for granting rights to connect to the electricity grid was issued, awarding rights for more than 3,000 MW of wind power. The second tender, for connection rights of up to $1,700 \mathrm{MW}$, was issued in 2005 and also included evaluation criteria aimed at creating an industrial cluster in renewable energies: the winning bids had to include setting up factories for wind turbine manufacture in the deprived areas of the country, in order to generate employment, limit imports and boost exports.

Successive Energy Policy Plans in 20034, $2005^{5}$ and $2010^{6}$ and the 2010 National Action Plan for Renewable Energies (following the 2009/28/CE Directive, of April 23, 2009) established more ambitious targets for renewable energy, as well as sets of measures to achieve them, several of which concerning wind energy: higher feedin tariffs, fiscal incentives, green certificates (through which companies are financially rewarded for the environmental benefits of generating renewable energy), simpler and swifter planning procedures, a new tender for connection rights (which has not been launched yet) and funding for R\&D projects.

All these policy measures have mostly favoured large companies, which have bought the bulk of renewables licences, rather than individual or community operators - which are predominant in Germany and Denmark (Devine-Wright, 2005; Warren et al., 2005; Breukers \& Wolsink, 2007; Toke, Breukers \& Wolsink, 2008). Much like in Spain, which has a similar level of wind energy development (Toke, Breukers \& Wolsink, 2008), all windfarm developers in Portugal are large companies: over $80 \%$ of the market share is held by just 10 developers, four of which are responsible for approximately $60 \%$ of the market share (INEGI, 2013). These four developers are in fact just three companies: EDPr (a branch of the major electric utility company in Portugal), Iberwind (a holding owned by several private equity companies, solely dedicated to wind energy, formed in 1998), Generg (a group owned by a SICAV fund, an open-ended collective investment scheme, and a French multinational electric utility company, that besides windfarms also manages hydroelectric dams and solar power plants) and ENEOP, a consortium of companies (including the three mentioned) that responded to the second tender. These large companies were able to make the bulky investment necessary for building a large number of windfarms in a short amount of time.

The fact that planning decisions on the siting of windfarms are taken at the national level can partly explain such high success rates, as in the Spanish case (cf. Wolsink, 2007a; Toke, Breukers \& Wolsink, 2008). Permissions for setting up energy generating facilities are granted by the Energy Department (usually under the Ministry of Economy). EIA, which are mandatory only for larger windfarms (over 20 turbines) located near already existing 
ones or in protected areas, fall under the jurisdiction of the national Environmental Agency. Smaller windfarm projects in Natura 2000 sites are required to perform an Environmental Effect Assessment (EEA), whose decision is issued by regional authorities. $^{\text {? }}$

Between 2000 and 2012, 131 EIA procedures regarding windfarms were conducted, namely, concerning the construction of new farms and the setting up of more turbines in existing ones. Contrary to what happens in other countries, such as the UK and the Netherlands (Bell, Gray \& Haggett, 2005; Toke, 2005; Wolsink, 2007a; Loring, 2007; Aitken, 2009; van der Horst \& Toke, 2010; Haggett \& Futák-Campbel, 2011), the vast majority of windfarm projects were approved $(71 \%)$ and only $8 \%$ were rejected (the remaining were withdrawn by the promoter or found in breach of EIA rules). Local councils also have to give their approval to windfarm projects, by signing an agreement with the developer. But, since developers are legally obliged to pay them a monthly fee of $2.5 \%$ of the windfarm revenue, in the vast majority of cases that approval is granted.

With the economic downturn and a change of government in 2011, renewable energy policy suffered a slight reversal. High feed-in tariffs and their costs for consumers had come under heavy criticism from the opposition party (during previous governments) and supporters of other energy sources, namely, the "nuclear lobby". The new government renegotiated the feedin tariff agreements and revised the National
Action Plan for Renewable Energies, ${ }^{8}$ with the aim of reducing costs and rebalancing the targets in view of the reduction in demand for electricity, favouring the increase in power in existing windfarms over the construction of new ones. However, the impact of this new policy trend is not noticeable yet.

Overall, it can be said that the development of wind energy in Portugal in the last decade can be attributed to strong policy incentives, centralised planning and decision-making, as well as the investment of large companies in this sector. The question now is: since some literature cited above also postulates that civil society support/opposition (both in terms of general public and local communities) can help/hinder the development of renewable energies, how is the case of Portugal similar or different from other cases reported?

\section{At the National Scale: Public Opinion on Wind Energy}

There are few sources from which to gauge the evolution of public opinion regarding wind energy in Portugal, since Eurobarometer surveys do not maintain regular series of data on this issue. Our analysis will, thus, focus on more recent surveys, comparing the way Europeans and the Portuguese population perceive the present and future roles of RE in the energy mix, with a particular emphasis on wind energy.

When it comes to expressing an attitude towards wind energy, the Portuguese show a

Table 1. Attitudes towards wind energy (\%).

\begin{tabular}{|c|c|c|c|c|}
\hline & In favor & Balanced & Opposed & Don't know \\
\hline EU 25 & 82 & 6 & 6 & 5 \\
\hline PT & 78 & 3 & 3 & 16 \\
\hline
\end{tabular}

Source: Eurobarometer 65.3 (2007) 
tendency to be less favourable to this power source than Europeans in general (Table 1), but that happens not so much as an expression of disagreement, but mostly due to the number of people who feel unable to answer this question. This is more due to lack of knowledge than to a clear opposition.

When we stretch the timescale to 2050 (Table 2), we can find some differences between the opinions of Portuguese and Europeans regarding future visions of $\mathrm{RE}$ use. Thus, in a recent Eurobarometer survey (2011), the Portuguese were amongst a small group of European countries (including Poland, Romania, Italy, Lithuania, Bulgaria and Hungary) that were less likely to believe in the wide use of wind and solar power as energy sources in 2050 (Table 2). The most positive outlook came from Denmark (82\%) and Sweden $(79 \%)$ (see also Ek, 2005). Moreover, $10 \%$ of Portuguese citizens (against $4 \%$ of Europeans) answered “don't know" to this question, which shows a difficulty in perceiving the role of RE in the future.

Table 2. Expectations of using renewable energy sources (e.g. wind and solar power) more than now in 2050 (\%).

\begin{tabular}{|l|c|c|}
\hline & PT & EU25 \\
\hline Yes, definitely & 32 & 51 \\
\hline Yes, probably & 50 & 38 \\
\hline No, probably not & 5 & 4 \\
\hline No, definitely not & 1 & 1 \\
\hline No change & 2 & 1 \\
\hline Don't know & 10 & 5 \\
\hline
\end{tabular}

Source: Eurobarometer 75.4, (2011)

Such results may be attributed to several factors. On the one hand, attitudes towards wind energy in Portugal tend to be more favourable in social groups with a higher educational attainment, and literacy levels in Portugal are low. Second, there has been a clear increase in the number of windfarms in Portugal, particularly since 2004 (see above). The more marked presence in the landscape and the need to live with some of the less positive aspects of these energy infrastructures might form the basis of a slightly less favourable attitude towards wind energy, when compared to the European average. As has been seen in case studies around Europe, especially when analysing local cases of opposition to this source of energy, different reasons emerge as justification and many are related to factors such as noise, pollution, health effects, impacts on wildlife or aesthetical and cultural values resulting from the need to live daily with these energy infrastructures (Nadaï \& van der Horst, 2010; Wolsink, 2007a; Cowell, 2010; DevineWright \& Howes, 2010; Havas \& Colling, 2011; Krough, 2011; Phillips, 2011). Along with this increased visibility, there is another possible explanation that has more to do with the public debate around the costs of $\mathrm{RE}$ and incentives that are being given to RE producers and its impacts on energy prices for the consumer. Although this needs to be confirmed with other empirical data (notably from media analysis), we believe that this debate may have contributed to a change of opinion regarding RE, particularly in a context of economic crisis.

\section{At the National Scale: ENGO Positions on Renewable Energy}

According to several authors (Wolsink, 2000; Toke, 2005; Eltham, Harrison \& Allen, 2008; Toke, Breukers \& Wolsink, 2008), ENGOs, in particular the ones dedicated to landscape protection, have also been instrumental in contesting or even blocking the construction of windfarms, whereas their absence (such as in Spain) has been used to explain the success of wind energy projects. 
In Portugal, a similar situation occurs. At the national level, however, there are no specialized landscape protection ENGOs. Three of the twelve national ENGOs can be described as "generalist", in the sense that they act in a variety of fields (nature conservation, energy, climate change, water issues, etc.) and the others are focused on wildlife (birds, wolves), leisure activities, animal rights, organic farming, or heritage. At the local level, ENGOs tend to campaign on a variety of issues, including landscape protection.

Only a handful of ENGOs carry out activities on the issue of wind energy, since, on energy matters, hydroelectric dams are a much more pressing issue for Portuguese ENGOs. ${ }^{9}$ Activities concerning RE take the form of awareness campaigns (with dissemination materials, such as booklets), participation in scientific seminars, publication of reports (for example, on the impact of windfarms on birds), media statements or press releases, written comments to EIA processes and judicial actions (e.g. injunctions, lawsuits, complaints to the European Commission).

Regarding their stance on RE, no significant differences were found between the discourses of "generalist" and specialised ENGOs. Almost all interviewees took care to highlight the role of RE sources in climate change mitigation and the dire need to replace fossil fuels, in what could be a case of what Haggett and Futák-Campbel (2011: 213-214) identified as a "disclaimer", a means for "avoiding the dismissal of one's claims as being biased, ill thought through, or just what would be expected of someone in this position, and orienting to the fact that wind power is thought to be popular":

We obviously acknowledge the serious problems our planet is facing, connected to the greenhouse effect and to the depletion of the ozone layer, and climate change on a global level, and we recognise that fossil fuels are the main responsible for climate change. [...] And so we are favourable in general to the replacement of carbon based energy by energy from renewable, non-polluting sources (Interview ENGO6).

However, all also highlighted the existence of negative environmental impacts and the need to evaluate them and to strike a balance between the protection of different values, an ambivalence also identified in other studies concerning ENGOs' stance on RE (Walker, 1995; Bell, Gray \& Haggett, 2005; Warren et al., 2005; Breukers and Wolsink, 2007):

We are obviously in favour of renewa-
bles. But there are two principles we
advocate: the cost/benefit principle
and the precautionary principle. Both
in wind and solar power, we have very
negative impacts, especially in wind
energy, due to the turbines and the
choice of the location. [...] And when
we don't know the potential negative
effects, we shouldn't build. [...] The
second principle is how far should we
invest when there are better forms of
generating energy or better solutions
(Interview ENGO2).

Conversely, much of the discourse of ENGOs representatives on windfarms tends to focus on its negative effects. They use much the same justifications that are commonly mentioned in the literature (Wolsink, 2000; Devine-Wright, 2005; Warren et al., 2005; Barry, Ellis \& Robinson, 2008; Eltham, Harrison \& Allen, 2008; Cowell, 2010) and in the public consultations of EIA (see below): the endangerment of animal and plant species, the defacement of natural and cultural landscapes, and the noise of the turbines. In most interviews, especially with 
ENGOs focused on nature conservation, the macrogeneration of RE is an option that should best be avoided, in favour of energy efficiency (a similar discourse to ENGOs in other countries, cf. Barry, Ellis \& Robinson, 2008).

ENGOs are also highly critical of the way the process of expanding RE has been conducted in Portugal, namely, the lack of planning and the "rush", which is an argument also identified by other studies (Warren et al., 2005; Cowell, 2010; Haggett \& Futák-Campbel, 2011; Jobert, Laborgne \& Mimler, 2007):

First, they should have done an overall study and then, after this study, analysing its impacts, its advantages, then use the solar and wind energy. [...] The government should have planned all this. (Interview ENGO3).

Another point of contention is the favouring of concentrated production and large companies, instead of the more consensual community-owned production (Breukers \& Wolsink, 2007):

The investment in microgeneration is bound to fail. If this continues to be controlled by two or three companies, there is no room for individual investors. If you have a two acre farm, you could place there a couple of solar panels or a couple of turbines. But, you face a lot of hurdles, you have no incentives and you must supply the power to the network, instead of using it directly. It's just a lot of obstacles, there is no political will; there has never been any political will to solve this and to allow the use of more renewables. The political power is stuck on three or four electrical companies in Portugal (Interview ENGO6).
Nevertheless, severalinterviewees expressed concerns at the change in political priorities since the current government came to power in 2011. Tax incentives for RE have been revoked, subsidies have been reduced and new legislation under discussion would end the acquisition and tariff guarantees, which will severely discourage energy producers from investing in RE.

ENGOs are also quite dissatisfied with how the media is portraying RE. In accordance with a strong policy emphasis in the implementation of RE in the country, these technologies gained a "very positive" image, as one interviewee says, being conveyed as harmless and misleading the media into disregarding its negative impacts (this was also pointed out by Afonso and Mendes, 2010):

There is in society the big dogma that this [renewable energy] is the solution, this will solve [...]; this is very good, there is absolutely no problem with this. And I think that sometimes even the media end up not making a very thorough search of what are the negative impacts associated with this and, above all, what are the alternatives (Interview ENGO2).

The media could be a channel for claims-making by ENGOs. However, the media coverage of their claims and of environmental issues in general seems to be in a stage of gradual decline of public interest. One explanation offered for this phase of the attention cycle of environmental issues coverage is the current economic crisis that affects both the editors' perceptions of audience's interest and of what issues should be allocated greater salience, and also the media system itself, which is reflected in reductions of the number of reporters and the time they can devote to each story and, hence, their 
capability of conducting their own research. Additionally, due to their complexity, news coverage of energy issues requires some specialized and interdisciplinary knowledge that only a few reporters have (Horta, 2008).

\section{At the Local Scale: EIA of Windfarm Projects}

At the local level, it is the actual location of windfarms that may have an impact on the attitudes of civil society. In Wüstenhagen, Wolsink and Burer's (2007) model, this pertains to the dimension of community acceptance of renewables. In Portugal, there is only one offshore windfarm, since the coastal sea bed is too deep. Most windfarms are located in mountain ranges in the North and Centre regions of the country, as well as close to the coast north of Lisbon. Moreover, the most favourable locations for windfarms tend to coincide with natural parks, protected landscapes and other conservation areas (Afonso \& Mendes, 2010), which raises a point of contention.

We have taken the Environmental Impact Assessment processes of windfarm projects - namely, participation in public consultation - as an indicator of civil society attitudes on wind energy at a local level. EIA procedures establish a mandatory public consultation period, in which the Non-Technical Report is made available and written comments from public and private entities are received. Although it is only a minority that participates in these procedures, these comments, favourable or unfavourable, can be taken as an indicator of attitudes towards local windfarm projects and shed light on potential controversies.

However, thelimitations of thesereportsas empirical evidence must be acknowledged. The conditions under which EIA public consultation takes place in Portugal have been the target of criticism, pointing out that the hearings are used mainly to inform the public rather than to foster debate (Lima, 2004: 154) and that various strategies are mobilized to discourage participation: scant publicity of projects, difficult access to documentation, failure to provide design alternatives, discussion of works already under construction (Chito \& Caixinha, 1993). As Gonçalves notes,
The difficulty of applying EIA legisla- tion in Portugal has its roots in a dou- ble institutional limitation, which has affected the incorporation of scientific and public opinion into EIA procedures. The relative weakness of the Portuguese scientific system and the lack of insti- tutionalised forms of scientific advice for public administration [...], together with an inactive civil society, has con- tributed to maintaining the status quo of traditional administrative practice, which is most typically centralised, hierarchized and secretive. (Gonçalves, 2002: 251)

In fact, out of the 76 public consultation reports (PRP) analysed in our research, only 44 mentioned the participation of civil society (citizens and nongovernmental organisations). The majority of comments are technical statements issued by government bodies, in charge of the environment, tourism and culture, national defence, communications, energy and transport, as well as regulators and large private companies in the same domains. Local authorities also sent written comments in slightly under half the cases of public consultation (32), of which the vast majority (56 in 61 comments) were in favour of windfarms (especially because they receive financial compensation, as mentioned above), albeit stipulating conditions in most cases. 


\section{Citizen participation in EIA}

In the last decade, citizens participated in only 24 of the 76 public consultations regarding windfarms. In total, we identified 40 written comments from citizens, citizen groups and local entrepreneurs, concerning 30 windfarm projects to be implemented in different parts of the country. We found both favourable and unfavourable comments from citizens regarding the windfarms, although the EIA limitations stated above prevent us from drawing firm conclusions on the local communities' responses based on the number of positive and negative comments. Concerning the outcome of these 30 windfarm projects, only four were rejected and one was withdrawn by the promoter before the completion of the EIA, while the remaining were conditionally approved (though mitigation measures were imposed).

These comments enable us to draw a picture of the arguments in favour and against the siting of windfarms deployed by citizens. As shall be seen below, attitudes towards windfarms diverge mainly on account of impacts: whereas economic impacts can be seen both as an argument for and against windfarms, environmental and landscape impacts (as well as, on a smaller scale, effects on health and quality of life) are always mobilised to reject proposals.

As to the favourable comments, in line with international research (Woods, 2003; Toke, 2005; Jobert, Laborgne \& Mimler, 2007) and with the case study of the proposal for a windfarm in Montesinho (Afonso \& Mendes, 2010), citizens mostly underline the positive inputs windfarms bring to local development. For example, in one comment, 331 local residents "show support to the implementation of the project, for considering it as an asset that will contribute to a more sustainable development of the region and to national energy sustainability" (PCR 2255). Likewise, in another RPC, three local associations stated that they "welcome the implementation of the project, viewed as a great asset for this demographically and economically depressed region [...], [through] encouraging population growth and settlement" (PCR 772).

However, even favourable comments are often interspersed with some concerns. Two major issues emerge, the first of which is the route of power lines, which is referred to mainly in terms of health and visual impacts. Though the problems posed by power lines are far from exclusive to wind energy, the sheer number of windfarms (compared to other energy generating facilities, both renewable and non-renewable, far less frequent in Portugal) and their remote location has called for the construction of many more lines. For instance, regarding a windfarm project, the Commons Council ${ }^{10}$ argues that "a set of measures should be taken in order to mitigate the inherent impact", including

...monitoring of avifauna and the death of birds by collision, the placing of underground power lines [and] the reformulation of characteristics of wind turbines, the choice of colours to better frame the turbines [in the environment] [and] the use of architectural solutions: materials, colour, volume (PCR 1769).

The second recurring issue is the installation of wind turbines on lands whose owners were not previously notified. For example, with regard to several windfarm projects, one Commons Council states that "despite being in favour of the deployment of such infrastructure", complain that "it should have been contacted about the implementation of some wind turbines in the commons under its ownership" (RCP 1138 and 1139).

The unfavourable comments address several major recurring topics of concern. The first one relates to the environmental 
impact of the windfarms. For example, a local resident:

...refutes the information contained in the EIA due to multiple errors, namely, in terms of fauna and flora assessment and the conclusions presented. It considers that the Iberian wolf is particularly affected, because it is a species in danger of extinction and some wind turbines will be located in areas of high importance for the species, namely, reproduction areas (PCR 1769).

The second cause for complaint concerns the socio-economic impact of windfarms. Regarding another windfarm project, a local tourism entrepreneur criticizes the EIA due to:

...the low importance given to the natural values identified, the assessment of sound impact, [...] the compatibility of the project with the instruments of land management, the magnitude of the impact on the landscape, $[. .$.$] and$ the fact of not taking into consideration aspects related to Rural and Nature Tourism, currently the main points of local investment, in the analysis of socio-economic impact (PCR 2034).

Another major topic of concern, already mentioned in the previous quotation, is the impact on the landscape, often associated with the visual intrusion of turbines and overhead power lines and its negative effects on tourism, an issue also highlighted in research undertaken in other countries (e.g. Walker, 1995; Wolsink, 2000; Pasqualetti, 2001; Woods, 2003; Warren et al., 2005; Wolsink, 2007b; Eltham, Harrison \& Allen, 2008; Cowell, 2010; Devine-Wright \& Howes, 2010; Jobert, Laborgne \& Mimler 2007; Toke, Breukers \& Wolsink, 2008). Regarding one windfarm project, a local tourism company focusing on mountain and nature activities

...considers that the project should be located out of the [Serra da Estrela] Natural Park and the Mondego valley, since it will significantly affect the landscape and tourism, contributing to the desertification of this region. It refers that the impact on the landscape is huge, leading to the adulteration of nature and affecting the visual and sound quality, the harsh character, the diversity of shapes, colours and texture, and the pattern of calm that, until now, were the main assets of this region, attracting tourist flows from large cities and abroad. (PCR 2034)

A fourth topic of apprehension is the impact of windfarms on health, which is usually associated with overhead power lines, water contamination and noise. These concerns are increasingly echoed in the literature (Havas \& Colling, 2011; Krough, 2011; Phillips, 2011). For example, citizens living in a close-by village

... contest the implementation of four energy generators, for considering them too close to the village, and point out a number of negative effects, such as noise pollution, contamination of groundwater resources due to oil change of wind turbines, and even lack of knowledge about other negative impact such as radioactivity (PCR 978).

A final major topic of concern, already present in the previous quotation, is the impact on the quality of life of residents. One Commons Council is of the opinion that the local windfarm project "neglects aspects needed for the preservation of the quality of life of people" (PCR 1302). 
In conclusion, within the EIA, local opposition to windfarms by residents is scarce. First, most public consultations receive no comments from citizens, which can be construed both as a sign of acceptance (many windfarms are located in such remote areas that no populations are affected) or as evidence for the poor dissemination these participation procedures receive and a weak civil society in Portugal (Gonçalves, 2002). Second, when they do participate, several of the comments from citizens are in favour of windfarm projects. And in the case of unfavourable comments, they seem to have little impact on the administrative decision, since most windfarms are approved.

However, it should be noted that participation in public consultations is a restricted indicator of citizens' attitudes towards RE in specific local settings, albeit the only one that is able to give a general picture without resorting to an accumulation of case studies (which though valuable, are time and resources consuming and outside the scope of this article). Public consultation is mainly geared towards the expression of opposition rather than support (Bell, Gray \& Haggett, 2005). Literature shows that the acceptance of windfarms tends to grow over time, especially when they are already built (Wolsink, 2000, 2007a, 2007b; Pasqualetti, 2001; Bell, Gray \& Haggett , 2005; DevineWright, 2005; Warren, et al., 2005; van der Horst, 2007; Eltham, Harrison \& Allen, 2008). But also, controversies can occur after the EIA process, at the time of the construction or when the windfarms start to operate. Research has shown that local populations in Portugal have other ways of expressing dissatisfaction and protesting against what they perceive as environmental hazards, such as road blocks, public demonstrations and picketing at the proposed locations (Figueiredo \& Fidelis, 2003).

\section{ENGO participation in EIA}

Between 2001 and 2012, out of a total of 76 public consultations, only in 31 cases have ENGOs submitted written comments. We identified 55 comments from 17 ENGOs, six of a national scope (the ones covered by the interviews analysed above) and 11 of a local character. Local ENGOs usually submit comments only to one EIA, regarding a windfarm in their area of interest (an exception is a local ENGO that submitted seven comments, but it concerns an area in which there are multiple windfarm projects), whereas all national ENGOs have taken part in several EIAs. About a third of public consultations received comments from more than one ENGO (in two cases four ENGOs took part) and in five cases a group of ENGOs coordinated their efforts by submitting a joint written comment:

Once in a while [we act together]. The aim is to pull together resources. [...] So together we have a more powerful voice. (Interview ENGO5)

Absence of participation in public consultation of EIA should not be interpreted as unconditional support to the construction of the windfarms. The interviews with ENGO representatives also shed light on how ENGOs become involved in these processes. The role of local ENGOs or of local chapters of national ENGOs is crucial for signalling cases where intervention is needed to safeguard environmental interests. Where these groups or organisations do not exist, EIA of windfarms can go unnoticed:

Regarding windfarms, our criterion [for intervening] is whether there are impacts or not. But above all, what is more decisive is if there is a regional structure of ENGO2 in the vicinity of the windfarm. I fully admit that there 
may have been windfarms with impacts over the fauna or the landscape even worse than the ones we contested but just because there was no one there, no ENGO2 branch with the time, the experts or the motivation to complain. (Interview ENGO2)

The high number of processes and the wide range of fields in which ENGO act, as well as their lack of financial and human resources, makes it impossible for them to assess each case.

As expected, ENGOs comments were largely unfavourable to the construction of the windfarms ( 41 out of 55 comments). The remaining comments, though favourable to the construction, stressed the need for the inclusion of missing information in the EIA (such as the path of power lines and the number of pylons), the importance of taking into consideration the cumulative impacts of several windfarms in the same area and the inclusion of specific mitigation measures.

As to the unfavourable comments, a handful (especially in public consultation reports from the beginning of the decade) included an initial acknowledgement of the benefits of wind energy in terms of replacing fossil fuels and mitigating climate change (as well as other positive aspects, such as the turbines being manufactured in Portugal), followed for specific reasons for rejecting the project. But, the vast majority focused solely on the negative effects of windfarms.

The arguments presented by ENGOs focused mainly on environmental issues, such as the negative impact on animal species, especially birds and bats (excess mortality by collision and electrocution from power lines) and wolves (classified as an endangered species, windfarm construction disrupt their habitats, breeding habits and communication between different populations), on trees and vegetation, on habitats (loss or fragmentation), and on geological features. Social and cultural aspects are also mentioned: the negative impact on archaeological sites and monuments, the destruction of the landscape and the disturbance of local inhabitants, through noise from the turbines, devaluation of property, inconveniences caused by construction work and misuse of economic profit from land rental (construction of roads instead of social benefits and requalification of villages).

While in only one case the size of the windfarm (number of turbines) is cited, ENGO comments often mention cumulative effects of several windfarms in the same area and with other structures (roads, mines and quarries, hydroelectric dams) and the failure of individual EIA in accounting for them. Other sources of negative impacts pointed out by the ENGOs, besides the turbines and the windfarms themselves, are the construction works (widening roads, reinforcement of bridges, disturbance of local populations), the power lines that connect the windfarms to the grid (affecting especially birds and the landscape) and access roads: previously inaccessible, unspoilt areas become reachable, causing disturbances to fauna and flora, illegal hunt and collection of plants, and fire hazards.

Many ENGOs' unfavourable comments are based on the perceived deficiencies of the EIA: incomplete inventory of affected species, lack of cartographical detail, undervaluation or overlooking impacts, failure to consider alternative locations, insufficiency of mitigation measures. In many cases, the argumentation of ENGOs also points out the disregard of regulations, national legislation or European directives, by proposing to implement windfarms in protected areas (natural parks, Natura 2000, special areas for the conservation of animals and habitats). 
The tone of these comments is mostly objective, relying mainly on legal, technical and scientific arguments. As Aitken (2009) has demonstrated, expert knowledge carries far more weight than local knowledge in windfarm planning decisions. ENGOs rely on their own scientific resources to prepare these comments, since their members are usually highly qualified: many have Ph.D. in biology or environmental engineering, many are academics.

There are a few exceptions, chiefly from local, less professional ENGOs, that tend to use more emotional arguments in their comments: e.g. "The construction of these windfarms is an aggression that will endanger, in the medium and long run, the fundamental dual purpose of preserving and make profitable the mountain area" (PCR 1041). Arguments about the effects on the landscape also tend to be more expressive, relying on the use of adjectives and contrasting the artificial character of turbines with the natural character of landscape:

The landscape impact is undervalued, since it transforms one of the places where human presence is least felt into a highly artificial landscape, where 17 $126 \mathrm{~m}$ turbines will negatively affect its relation with the surrounding area, irredeemably transforming a scenery of rare beauty. [...] Having been created the Protected Landscape of the Mountain of Montejunto, and since preserving the landscape is the main motivation for the classification of these places, there is a clear paradox in setting up a windfarm at that location. (PCR 2449; emphasis added)

Despite the mostly negative statements of ENGOs, only in six cases did the final decision of authorities in these EIA cases go against the construction of the windfarms and these were mostly cases in which several ENGOs expressed a negative opinion, although some of the more contentious projects were approved, as also happens in other countries (cf. Bell, Gray \& Haggett, 2005). As seen above, most EIA decisions of windfarms have been favourable, and some ENGOs feel quite powerless in this regard:

The administration is impervious [to our negative comments]. [...] I think that ENGO activity on this issue in the past few years has had very few results. And when a windfarm isn't built, it's not because of the ENGOs. ENGOs bring the issue to the attention of public opinion, of media, and they help a little, they do. But the main role is played by the experts of the Environmental Agency (Interview ENGO1).

However, for other ENGOs, a conditional approval, listing mitigation measures for the windfarms, can be enough to allay their concerns. Nevertheless, ENGOs have other resources to try to prevent the construction of windfarms, namely, starting petitions, filing lawsuits and even complaints to EU authorities. These are on occasion successful and windfarm construction is stopped or restrictions are placed on their operation.

\section{Conclusion}

It is often said that social acceptance is a prime factor for the development of renewable energies, which have been touted as the main solution for mitigating climate change and addressing the foreseeable depletion of fossil fuel reserves. Local opposition to windfarms has been blamed for hindering their siting and is in contrast with strong public support for RE.

This article sought to contribute to the existing literature by discussing the case of 
a southern European country where wind energy development has been significant and swift, but that has been left out of international comparisons, Portugal. In a country that has made, during the last decade, a massive investment in RE generation, particularly through wind power, understanding social attitudes towards RE is a relevant endeavour. This was carried out by using a two scale analysis (national and local) and taking into account two types of social actors: ENGOs and citizens. Considering the national level, data from the public opinion surveys show a less favourable attitude of Portuguese citizens regarding wind energy, compared with their European counterparts. These results are reflected in the future of energy sources, as the Portuguese are more sceptical about the wide use of RE. This can be partly explained by the literacy and environmental information levels of Portuguese population (lower than the EU average), as well as by the rapid growth of windfarms and the recent public debate regarding the costs for the consumer at the onset of the economic crisis.

Empirical evidence from the analysis of the interviews with ENGOs representatives highlighted their ambivalence towards RE. In what Warren et al. (2005) called a "green on green" controversy, ENGOs support the development of clean energy but at the same time show concerns over the negative environmental effects of windfarms, and often oppose them at the local level, by participating in public consultations of environmental impact assessments with unfavourable comments, focusing mainly on negative environmental impacts (particularly regarding effects on local fauna and flora), as well as social and cultural aspects (mostly the destruction of the landscape). Other relevant apprehensions expressed by ENGOs are related to the way the process of expansion of RE has been conducted in Portugal (poor land use planning and top-down decision processes), the favouring of large companies in the production of wind energy (concentrating power in a few energy corporations) and the mass media coverage of RE, which fostered a very positive image, disregarding negative impacts and expert opinions.

At the local level, the analysis of the public consultation reports of EIA of windfarm projects allow us to conclude that social participation regarding this matter, as other spheres of social concern, is still scarce in Portugal. However, when citizens do participate, positive comments outnumber (although slightly) negative ones. These are mainly related to the positive impacts windfarms can have on local development. The main concerns expressed by citizens in these processes were related to five main topics: environmental impacts, socioeconomic impacts, landscape impacts often associated with the visual intrusion of the turbines and its negative effect on tourism, health impacts and negative effects on the quality of life of local population.

Thus, local attitudes towards windfarms are also varied. Local authorities and citizens tend to favour the siting of windfarms, whilst ENGOs, often sustained on legal and scientific evidence, tend to oppose them. Despite these objections, public administration nearly always approves the projects.

This is probably the main factor that explains the success of wind energy in Portugal. In line with the work on the policy and institutional framework of RE (see Table 3), Portugal has had (until now, at least) a highly attractive feed-in tariff system, but not the participatory open-ended approaches that explain the success of renewables in Germany and Denmark. Unlike the UK, Netherlands and France, where top-down planning of large scale developments has hindered the development of RE, in 
Portugal (and in Spain) a strong centralised and administrative tradition (inherited from an enduring authoritarian state that lasted between 1933 and 1974) that has yet to fully come to terms with open, democratic and participatory approaches, has led to an expansion of wind power, regardless of a less than enthusiastic public opinion and a sceptical environmental movement.
In addition, ownership of the windfarms is often private or a combined partnership of private-public sectors (as occurs in Spain), whereas community owned windfarms, that tend to be less controversial in other countries, are rare (Walker, 1995; DevineWright, 2005; Warren, et al., 2005; Wolsink, 2007a; Breukers \& Wolsink, 2007; Jobert Laborgne \& Mimler, 2007; Loring, 2007;

Table 3. Factors that support or hinder the development of renewables.

\begin{tabular}{|c|c|c|c|c|c|c|c|}
\hline & UK & $\begin{array}{c}\text { Nether- } \\
\text { lands }\end{array}$ & France & Germany & Denmark & Spain & Portugal \\
\hline \multicolumn{8}{|l|}{ Positive factors } \\
\hline Feed-in tariffs & & & & $\begin{array}{l}(3)(5)(7) \\
(9)(12)\end{array}$ & (7) (9) & (7) (9) & $\mathrm{X}$ \\
\hline $\begin{array}{l}\text { Participatory } \\
\text { approaches to } \\
\text { planning }\end{array}$ & & & & $\begin{array}{c}(3)(5) \\
(13)(14)\end{array}$ & $\begin{array}{l}\text { (6) (9) } \\
(13)\end{array}$ & & \\
\hline $\begin{array}{l}\text { Predominance of } \\
\text { local ownership of } \\
\text { facilities }\end{array}$ & & (9) & & (9) (11) & $\begin{array}{c}\text { (6) (9) } \\
(11)\end{array}$ & & \\
\hline $\begin{array}{l}\text { Government } \\
\text { intervention in } \\
\text { planning }\end{array}$ & & & & (7) (9) & (9) & (9) (14) & $\mathrm{X}$ \\
\hline $\begin{array}{l}\text { Support of ENGO/ } \\
\text { grassroots }\end{array}$ & & & & (3) (9) & (6) (9) & & \\
\hline \multicolumn{8}{|l|}{ Negative factors } \\
\hline Top-down planning & \begin{tabular}{|c|}
$(1)(2)(3)$ \\
$(4)(6)$ \\
$(10)(13)$ \\
\end{tabular} & (3) (12) & (5) (14) & & & (2) (9) & $\mathrm{X}$ \\
\hline \begin{tabular}{|l|} 
Insufficient \\
incentives
\end{tabular} & (3) (8) (9) & $\begin{array}{l}(3)(9) \\
(12)\end{array}$ & (5) (14) & & & & \\
\hline $\begin{array}{l}\text { Opposition of local } \\
\text { authorities }\end{array}$ & $\begin{array}{c}(3)(8)(9) \\
(11)\end{array}$ & $\begin{array}{c}(3)(9) \\
(14)\end{array}$ & (5) & & & & \\
\hline $\begin{array}{l}\text { Opposition of } \\
\text { ENGOs/landscape } \\
\text { protection groups }\end{array}$ & \begin{tabular}{|c|}
$(1)(2)(3)$ \\
$(4)(8)(9)$ \\
$(10)(11)$ \\
$(13)$ \\
\end{tabular} & (12) & (5) & & & & $\mathrm{X}$ \\
\hline $\begin{array}{l}\text { Predominance of } \\
\text { company ownership } \\
\text { of facilities }\end{array}$ & $\begin{array}{c}(6)(9) \\
(11)\end{array}$ & & (5) (14) & & & (9) & $\mathrm{X}$ \\
\hline $\begin{array}{l}\text { Slow uptake by } \\
\text { developers }\end{array}$ & (8) & & & & & & \\
\hline
\end{tabular}

(1) Bell, Gray \& Haggett, 2005; (2) Bell et al., 2013; (3) Breukers \& Wolsink, 2007; (4) Cowel, 2010; (5) Jobert, Laborgne \&Mimler, 2007; (6) Loring, 2007; (7) Ringel, 2006; (8) Toke, 2005; (9) Toke, Breukers \& Wolsink, 2008; (10) van der Host \& Toke, 2010; (11) Warren et al., 2005; (12) Wolsink, 2000; (13) Wolsink, 2007a; (14) Wolsink, 2007b. 
Toke, Breukers \& Wolsink, 2008) (see Table $3)$. Returning to Wüstenhagen, Wolsink and Burer's (2007) model, in Portugal political and market acceptance are, thus, assured, whereas communities and stakeholders are mostly ambivalent, but almost powerless against a centralised form of decisionmaking. This goes to show that when it comes to promoting renewable energies across Europe, "one size fits all" models are inadequate. Political and administrative practices and traditions have a strong bearing on the outcomes of energy policy.

Given the importance of institutional settings within varied national contexts to understand consensus or controversy of civil society attitudes regarding renewable energy, and particularly wind energy, it is suggested that future research could benefit from historical analyses of state and science co-evolution and their relationships with the market and civil society. The case of Portugal illustrates the need for more research on these relationships given much of the explanations for the findings of this study fell back onto some of the features of a heavy, centralised, highly hierarchized and secretive public administration inherited from the past, as poignantly noted by Gonçalves (2002).

\section{Acknowledgements}

This article is based on research for the project 'Socio-technical consensus and controversies about renewable energies' (www.renergyproj.ics.ul.pt), funded by the Portuguese Foundation for Science and Technology (PTDC/CS-ECS/118877/2010), carried out at the Institute of Social Sciences (University of Lisbon), in collaboration with the University of Aveiro and the Centre for Research in Anthropology.

\section{References}

Afonso, A. I. \& C. Mendes (2010) 'Energía Eólica Y Paisajes Protegidos: Controversias en el Parque Natural De Montesinhos', Nimbus 25-26: 5-19.

Aitken, M. (2009) 'Wind Power Planning Controversies and the Construction of "Expert" and "Lay" Knowledges',Science as Culture 18(1): 47-64.

Barry, J., G. Ellis \& C. Robinson (2008) 'Cool Rationalities and Hot Air: A Rhetorical Approach to Understanding Debates on Renewable Energy', Global Environmental Politics 8(2): 67-98.

Bell, D., T. Gray \& C. Haggett (2005) 'The "Social Gap" in Windfarm Siting Decisions: Explanations and Policy Responses, Environmental Politics 14(4): 460-77.

Bell, D., T. Gray, C. Haggett \& J. Swaffield (2013) 'Re-visiting the "Social Gap": Public Opinion and Relations of Power in the Local Politics of Wind Energy', Environmental Politics 22 (1): 115-35.

Breukers, S. \& M. Wolsink (2007) 'Wind power implementation in changing institutional landscapes: An international comparison', Energy Policy 35(5): 273750.

Cowell, R. (2010) 'Wind power, landscape and strategic, spatial planning: The construction of 'acceptable locations' in Wales', Land Use Policy 27(2): 222-32.

Chito, B. \& R. Caixinhas (1993) 'A participação do público no processo de avaliação do impacte ambiental', Revista Critica de Ciências Sociais 36: 41-55.

Dear, M. (1992) 'Understanding and Overcoming the NIMBY Syndrome,' Journal of the American Planning Association 58(3): 288-300.

Devine-Wright, P. \& Y. Howes (2010) 'Disruption to place attachment and the protection of restorative environments : A wind energy case study', Journal of Environmental Psychology 30(3): 271-80. 
Devine-Wright, P. (2005) 'Beyond NIMBYism: towards an integrated framework for understanding public perceptions of wind energy', Wind Energy 8(2): 125-39.

Ek, K. (2005) 'Public and private attitudes towards "green" electricity: the case of Swedish wind power, Energy Policy 33(13): 1677-89.

Eltham, D. C., G. P. Harrison \& S. J. Allen (2008) 'Change in public attitudes towards a Cornish windfarm: Implications for planning, Energy Policy 36(1): 23-33.

EC European Commission (2007) Communication from the Commission to the European Council and the European Parliament: An Energy Policy for Europe (COM(2007) 1 final), Brussels: European Commission

EC European Commission (2010), Europe 2020 A European strategy for smart, sustainable and inclusive growth. COM(2010) 2020. Brussels: European Commission

Eurostat (2011) Energy, transport and environment indicators 2011 Luxembourg: Publications Office of the European Union.

Eurostat (2013a), Electricity generated from renewable sources - annual data [nrg_ind_333a], Energy Statistics - Main indicators.

Eurostat (2013b), Supply, transformation, consumption - renewables (hydro, wind, photovoltaic) - annual data [nrg_1072a], Energy Statistics - quantities.

Figueiredo, E. \& T. Fidélis (2003) “'No meu quintal, não!" Contributos para uma análise dos movimentos ambientais de raiz popular em Portugal (1974-1994), Revista Crítica de Ciências Sociais 65: 151-173.

Gonçalves, M. E. (2002) 'Implementation of EIA directives in Portugal How changes in civic culture are challenging political and administrative practice, Environmental Impact Assessment Review 22: 249-269.
Haggett, C. \& D. Toke (2006) 'Crossing the Great Divide - Using Multi-method Analysis to Understand Opposition to Windfarms', Public Administration 84(1): 103-120.

Haggett, C. \& B. Futák-Campbell (2011) 'Tilting at windmills? Using discourse analysis to understand the attitudebehaviour gap in renewable energy conflicts', Journal of Mechanisms of Economic Regulation 1(2): 207-20.

Havas, M. \&D. Colling (2011) 'Wind Turbines Make Waves: Why Some Residents Near Wind Turbines Become Ill', Bulletin of Science, Technology and Society 31(5): 414-26.

INEGI (2013) Windfarms in Portugal (Porto: INEGI/APREN), available: http:// e2p.inegi.up.pt/relatorios/Portugal_ Parques_Eolicos_201312.pdf

Horta, A. (2008) 'The production of news about energy as an environmental issue. Communication Policies and Culture in Europe', in ECREA Barcelona 2008. Programme, abstracts, posters and papers (Barcelona: ECREA), CD-ROM.

Jobert, A., P. Laborgne \& S. Mimler (2007) 'Local acceptance of wind energy: Factors of success identified in French and German case studies, Energy Policy 35(5): 2751-60.

Lima, M.L.P. (2004) 'Images of the public in the debates about risk: consequences for participation', Portuguese Journal of Social Sciences 2(3): 149-163.

Loring, J.M. (2007). 'Wind energy planning in England, Wales and Denmark: Factors influencing project success', Energy Policy 35(4): 2648-60.

Nadaï, A. \& D. van der Horst (2010) 'Wind power planning, landscapes and publics', Land Use Policy 27(2): 181-184.

Pasqualetti, M. J. (2001) 'Wind Energy Landscapes : Society and Technology in the California Desert', Society and Natural Resources 14(8): 689-99. 
Phillips, C. V. (2011) 'Properly Interpreting the Epidemiologic Evidence About the Health Effects of Industrial Wind Turbines on Nearby Residents', Bulletin of Science, Technology and Society 31(4): 303-315.

Ringel, M. (2006) 'Fostering the use of renewable energies in the European Union: the race between feed-in tariffs and green certificates, Renewable Energy 31(1): 1-17.

Toke, D. (2005) 'Explaining wind power planning outcomes: Some findings from a study in England and Wales', Energy Policy 33 (12): 1527-39.

Toke, D., S. Breukers \& M. Wolsink (2008) 'Wind power deployment outcomes: How can we account for the differences?', Renewable and Sustainable Energy Reviews 12(4): 1129-1147.

van der Horst, D. \& D. Toke (2010) 'Exploring the landscape of windfarm developments; local area characteristics and planning process outcomes in rural England,' Land Use Policy 27(2): 214-21.

van der Horst, D. (2007) 'NIMBY or not? Exploring the relevance of location and the politics of voiced opinions in renewable energy siting controversies,' Energy Policy 35(5): 2705-2714.

Walker, G. (1995) 'Renewable energy and the public', Land Use Policy 12(1):49-59.

Warren, C., C. Lumsden, S. O'Dowd \& R. Birnie (2005) “Green On Green': Public perceptions of wind power in Scotland and Ireland, Journal of Environmental Planning and Management 48(6): 853875.

Wolsink, M. (2000) 'Wind power and the NIMBY-myth: institutional capacity and the limited significance of public support', Renewable Energy 21(1): 49-64.

Wolsink, M. (2007a) 'Planning of renewables schemes: Deliberative and fair decisionmaking on landscape issues instead of reproachful accusations of noncooperation', Energy Policy 35(5): 26922704.
Wolsink, M. (2007b) 'Wind power implementation: The nature of public attitudes: Equity and fairness instead of 'backyard motives', Renewable and Sustainable Energy Reviews 11(6): 11881207.

Woods, M. (2003) 'Conflicting Environmental Visions of the Rural: Windfarm Development in Mid Wales', Sociologia Ruralis 43(3): 271-288.

Wüstenhagen, R., M. Wolsink \& M. Burer (2007) 'Social acceptance of renewable energy innovation: An introduction to the concept', Energy Policy 35(5): 2683-91.

\section{Notes}

1 Decree-Law n. 189/88, May 271988.

2 Decree-Law n. 168/99, May 18, 1999.

3 Resolution of the Council of Ministers n. 154/2001, September 27, 2001.

4 Resolution of the Council of Ministers n. 63/2003, April 28, 2003.

5 Resolution of the Council of Ministers n. 169/2005, October 24, 2005.

6 Resolution of the Council of Ministers n. 29/2010, April 15, 2010.

7 Decree-Law n. 69/2000, May 3, 2000; Joint Dispatch of the Ministers of Economy and Enviroment and Territorial Planning n. 583/2001, July 3 , 2001.

8 Resolution of the Council of Ministers n. 20/2013, April 10, 2011.

9 The National Program of Dams with High Hydroelectric Potential, created in 2007, foresees the construction of ten large scale projects with severe environmental impacts.

10 These nearly extinct traditional structures have gained a new lease on life due to wind farms, since a great number of projects fall under their jurisdiction and they are in charge of negotiating conditions and redistributing benefits (Afonso \& Mendes, 2010). 
Ana Delicado

Institute of Social Sciences

University of Lisbon

Av. Prof. Anibal de Bettencourt, 9

1600-189 Lisbon, Portugal

ana.delicado@ics.ulisboa.pt

Luís Junqueira

Institute of Social Sciences

University of Lisbon

Av. Prof. Anibal de Bettencourt, 9

1600-189 Lisbon, Portugal

luis.junqueira@ics.ulisboa.pt

Susana Fonseca

ISCTE-IUL

Av. das Forças Armadas, ed. ISCTE

1649-026 Lisbon, Portugal

susanafonseca@yahoo.com

Mónica Truninger

Institute of Social Sciences

University of Lisbon

Av. Prof. Anibal de Bettencourt, 9

1600-189 Lisbon, Portugal

monica.truninger@ics.ulisboa.pt
Luís Silva

Centre for Research in Anthropology

Av. de Berna, 26 C

(CRIA/FCSH-UNL), Edificio ID

1069-061, Lisbon, Portugal

luis.silva98@gmail.com

Ana Horta

Institute of Social Sciences

University of Lisbon

Av. Prof. Anibal de Bettencourt, 9

1600-189 Lisbon, Portugal

ana.horta@ics.ulisboa.pt

Elisabete Figueiredo

Department of Social, Legal and Political

Sciences

University of Aveiro

3810-193 Aveiro, Portugal

elisa@ua.pt 